\title{
Credibility of Digital Comic Media in Audio Visual Form on Style Topic for Elementary School Students
}

\author{
I Putu Oka Sastrawan 1*, I Gede Margunayasa ${ }^{2 *}$, Gede Wira Bayu ${ }^{3 *}$ iD \\ 1,2,3 Pendidikan Guru Sekolah Dasar, Universitas Pendidikan Ganesha, Singaraja, Indonesia \\ *Corresponding author: okasatrawan26@gmail.com
}

\begin{abstract}
Abstrak
Kurangnya kreativitas guru dalam pembelajaran untuk mengembangkan media pembelajaran membuat pembelajaran menjadi kurang efektif. Oleh sebab itu perlunya pengembangan media yang mampu membuat siswa menjadi antusias dalam belajar contohnya seperti komik digital. Penelitian ini menghasilkan product berupa media Komik Digital Pada Topik Gaya Siswa SD yang teruji validitasnya. Model yang digunakan adalah model ADDIE dengan tahapannya Analyze, Design, Development, Implementation, Evaluation. Dalam penelitian ini media komik digital dijadikan sebagai subjek penelitian adalah 2 orang dosen ahli media, 2 orang ahli materi, 2 orang guru. Metode dan instrumen pengumpulan data pada penelitian ini ialah menggunakan metode rating scale. Untuk mengukur validitas dari media komik digital menggunakan instrumen penilaian validitas media komik digital. Hasil data yang telah diperoleh akan dianalisis menggunakan rumus indeks validitas Aiken untuk data para ahli dan rumus mean untuk data para responden guna mengetahui validitas media komik digital. Hasil validitas media pada analisis indeks validitas Aiken penilaian para ahli mendapat skor sebesar 0,95 dari ahli materi dengan kriteria "validitas tinggi”, 0,95 dari ahli media dengan kriteria "validitas tinggi", sedangkan pada analisis skor penilaian dari para responden menggunakan rumus mean memperoleh rata-rata sebesar 4,57 dari respons praktisi dengan predikat "sangat baik", 4,50 dari respons siswa dengan predikat "sangat baik". Jadi, media komik digital sangat cocok digunakan saat proses pembelajaran khususnya pembelajaran IPA.
\end{abstract}

Kata kunci: Komik Digital, Audio Visual, IPA

\section{Abstract}

Lack of teacher creativity in learning to develop instructional media makes learning less effective. Therefore, it is necessary to develop media that can make students enthusiastic about learning, such as digital comics. This research produces a product in the form of Digital Comic media on elementary school student style whose validity has been tested. The model used is the ADDIE model with the stages of Analyze, Design, Development, Implementation, Evaluation. In this study, digital comic media used as research subjects were 2 media expert lecturers, 2 material experts, 2 teachers. The method and instrument of data collection in this study is to use the rating scale method. To measure the validity of digital comic media using an instrument to assess the validity of digital comic media. The results of the data that have been obtained will be analyzed using the Aiken validity index formula for expert data and the mean formula for respondents' data in order to determine the validity of digital comic media. The results of the media validity on the Aiken validity index analysis, the assessment of the experts, got a score of 0.95 from the material experts with the criteria of "high validity", 0.95 from the media experts with the criteria of "high validity", while the analysis of the assessment scores of the respondents used the formula. The mean obtained an average of 4.57 from the practical response with the predicate "very good" and 4.50 from the student response with "very good". So, digital comic media is very suitable for use during the learning process, especially science learning.

Keywords: Digital Comics, Audio Visual, IPA

\begin{tabular}{|c|c|c|}
\hline History: & & Publisher: Undiksha Press \\
\hline Received & : March 19, 2021 & Licensed: This work is licensed under \\
\hline Revised & : March 21, 2021 & a Creative Commons Attribution 3.0 License \\
\hline Accepted & : June 20, 2021 & (c) (1) () \\
\hline Published & : July 25, 2021 & EY SA \\
\hline
\end{tabular}

\section{Introduction}

Rapid advances in technology and information require innovation in the world of education (Astuti et al., 2021; Muhtadi et al., 2018). Facing future challenges, what needs to be prepared is to equip students with higher-order thinking skills, such as problem-solving skills and critical thinking, through a meaningful learning process (Rovers et al., 2018; Sung, 
2017). The learning process by providing direct experience to students through scientific activities is the main focus in implementing science content learning (Jundu et al., 2020). Scientific activities in science learning allow students to build their knowledge by applying the concepts they have learned and making learning more meaningful (Lo et al., 2021; Maison et al., 2020).

The scientific activities in question are discussions, investigations, simulations or project activities (Fauzan et al., 2017; Suryantari et al., 2019). In addition, student-centred science learning activities positively impact students' creativity and learning motivation (Huang et al., 2020; Perignat \& Katz-Buonincontro, 2019). This can be realized by presenting media in the learning process. Media provides several benefits in the learning process, such as: clarifying the meaning of the message conveyed because it uses concrete objects, making learning more attractive to increase student interest in learning, increasing student focus in learning, and of course, improving student learning outcomes (Hidayah et al., 2018; Jampel and Puspita 2017; Lestari 2018).

However, in reality, the use of learning media can be said to be not optimal. The results of interviews with homeroom teachers for grade IV SD in Cluster VII, Buleleng subdistrict have been carried out. The reality is that the use of media during the learning process is still shallow and less than optimal in the field. Teachers still focus on only using books obtained from schools without developing or not using media and learning. The lack of teacher innovation in developing media according to student characteristics is also an obstacle. Utilizing the convenience of technology in today's era and combining it with learning materials can make the conditions of the atmosphere during the learning process more enjoyable and not seem monotonous for students.

This is also reinforced by several studies which state that teachers have not optimally utilized the media in the learning process (Abdullah, 2017; Lastefo, 2018; Lestari, 2018). The impact of the lack of use of media in the learning process is that it causes low student motivation to learn, leading to low student learning outcomes themselves. This is evident from the results of PISA stating that in 2018 the Science ability of students in Indonesia received an average score of 389 with an average OECD score of 489, the results were down compared to the previous PISA results, namely in 2015 (Herreras, 2017; Indriani, 2019; Nugrahanto \& Zuchdi, 2019). If this event continues to be left unattended without any further action, then the understanding of science or science students in Indonesia will decline and fall further from what is desired (Genc et al., 2018; Permana \& Nourmavita, 2017).

The research on the development of learning media was carried out (Arista \& Kuswanto, 2018; Shaik Alavudeen et al., 2021). The developed media aims to assist teachers in implementing the science content learning process, especially on the topic of style, so that students have high motivation in participating in learning (Puspitarini \& Hanif, 2019; Saripudin et al., 2018). One of the relevant media to be developed is digital comic media. Digital comics are comics with simple picture stories in a series presented in electronic digital media (Y. F. Hidayah et al., 2017; Taufiq et al., 2020). Another opinion states that digital comics are digital-based electronic comics that can display the storyline and insert games, animations, films, and other applications so that readers can easily understand and appreciate each storyline and can be accessed online (Dwiasih \& Agung, 2021).

Technology that is appropriately used in learning activities will optimize learning outcomes (Astuti et al., 2021; Chauhan, 2017; Tuma, 2021). The advantages of comics are: (1) Comics can increase the vocabulary of their listeners, (2) Able to develop students' interest in listening and reading, (3) Can make it easier for children to catch abstract formulas, (4) The way of comic stories refers to one thing is an excellent opportunity and other fields of study (Riwanto \& Wulandari, 2018). The results of the study stated that the use of digital comic media in the learning process had an impact on increasing interest in 
learning, critical thinking skills and student learning outcomes (Andriani, 2019; E. Sukmanasa et al., 2017; Yuniarti \& Radia, 2020).

However, the weakness of digital comic media in these studies is that the media is only in the form of images equipped with text according to a predetermined plot. It is different from the digital comic media developed in this study, namely: packaged in audiovisual videos, containing unique characters, exciting backgrounds with full colour, the voices of each character in conveying the material, and accompaniment music to add to the story. The atmosphere while listening to it. In addition, the topic of discussion is the topic of style in the fourth grade of elementary school. The findings of previous research stated that comics could be used as learning media (Koesoemadinata, 2018; Yulianti et al., 2016). Other research findings also state that E-comic can help students learn, thereby increasing student enthusiasm (Hobri et al., 2019; Rahmata et al., 2020). Based on this research, it can be concluded that comics can be used in learning. This study aims to develop digital comic media in the form of audio-visual on the topic of style for elementary school students. The hope of developing this media is to increase the active role of students in learning and increase students' understanding of the topic of style.

\section{Methods}

This research is research that produces a product. The product developed in this research is digital comic media on the topic of style. The model used in this study is the ADDIE model (analyze, design, development, implementation, evaluation) (Wulandari et al., 2020). The analysis stage is done by analyzing student characteristics, analyzing curriculum, analyzing media, and analyzing needs. The analysis of student characteristics is carried out by measuring the knowledge, attitudes, and abilities that are the target of using comics media. The design stage is focused on selecting material content according to the needs of students' characteristics and demands for competencies developed in digital comic media, making digital comic designs as a whole starting from media covers, storylines, character creation, to cover covers. Then the design is shown to the supervisor to get input and suggestions so that revisions can be made, then the draft from the media that has been revised, then the development stage can be carried out. The media development stage can already be made according to the design results and has been consulted with the supervisor. If the media has been developed, it can proceed to the assessment stage through an assessment test from media expert tests, material expert tests, practitioner responses, and student responses to review digital comic media developed.

In the implementation stage, the development results are applied during the learning process to find out how the effectiveness, attractiveness, and efficiency of learning affect the use of digital comics developed. Due to the conditions in the field and the circumstances that do not allow this stage can not be carried out. The evaluation stage is the last. This stage is carried out an objective assessment to determine the quality of the comic media and to find out whether the digital comic media that has been developed can significantly affect student learning outcomes. Due to the conditions in the field and the circumstances that do not allow this stage can not be carried out.

The subjects in this development research are experts who are competent in their fields, where the experts consist of 2 material experts, 2 media experts, 2 teachers and 6 students. Furthermore, the data collection method was carried out by the questionnaire method, namely by providing a list of questions or statements to the respondents. At the same time, the instrument used in the study, namely the rating scale. The scale used on the rating scale is 1-4 (Ilhami \& Rimantho, 2017). The grid of the learning video validation sheet can be seen in the following table. 
Table 1. Digital Comic Media Validity Sheet Grid for Material Experts

\begin{tabular}{|c|c|c|}
\hline \multirow{3}{*}{$\frac{\text { No. }}{1}$} & Aspect & Dimensions \\
\hline & Material/ content & $\begin{array}{l}\text { Completeness and clarity in } \\
\text { convey identity }\end{array}$ \\
\hline & & Delivery of clear learning objectives \\
\hline 2 & Language/ & Submission of material clearly \\
\hline & Communication & Appropriateness of the use of language rules \\
\hline 3 & Presentation & $\begin{array}{l}\text { Use easy-to-understand language } \\
\text { To the sequence in the presentation }\end{array}$ \\
\hline
\end{tabular}

Table 2. Digital Comic Media Validity Sheet Grid for Media Experts

\begin{tabular}{lll}
\hline No. & \multicolumn{1}{c}{ Aspect } & \multicolumn{1}{c}{ Dimensions } \\
\hline 1 & Voice and text & The text is presented clearly \\
2 & Visual & Voice is presented clearly \\
& & $\begin{array}{l}\text { Illustrations are clearly presented } \\
\text { Interesting background display } \\
\text { Combination in the use of colors }\end{array}$ \\
3 & Characterizations & $\begin{array}{l}\text { Character selection } \\
\text { The Attractiveness of the Characters }\end{array}$ \\
4 & Overall view & Overall look
\end{tabular}

The instruments that have been prepared are then carried out at the validity test stage. A validity test was conducted to determine the level of validity of the instrument by using the Gregory formula. After the data has been collected using the instrument, the data will be analyzed using qualitative descriptive analysis techniques and quantitative descriptive analysis. Qualitative data is data obtained at the expert review stage in the form of suggestions and comments. Then from the data, improvements are made to the developed media by the suggestions and comments given so that it becomes a better media. While quantitative data is data obtained at the expert review stage in the form of scores on the assessment sheet, the data is calculated on average using the mean formula to obtain the results of the validity of the developed media. After the average is obtained, it is converted to a conversion table for the level of achievement on a scale of 5 .

\section{Results and Discussion Results}

The results of the analysis of student characteristics carried out can be seen that the characteristics of elementary school students are at the stage of concrete operational development aged 7-11 years, especially in children's cognitive development. When the learning process is needed, a tool to help clarify students in interpreting a material. The tool is a medium. Therefore, the use of media is essential to make the learning process more optimal for developing children. With the use of media during the learning process, especially in this case, digital comic media can attract students' attention so that they are happy in learning. It can be concluded that it is essential to have its existence during the learning process by utilizing learning media. The media can provide convenience for students to understand more the content of the material being studied. The analysis stage of the curriculum is carried out by analyzing the contents of the Indicators, $\mathrm{KD}$, and $\mathrm{KI}$ contained in the lesson plans and student textbooks so that they can be used as guidelines in the development of digital comic media. The material used is the topic of style based on KD. 
Analyzing the media aims to obtain information about how the criteria from the media are suitable for use so that the criteria obtained can be used as a reference. From the analysis conducted, it is stated that the criteria for media suitable for use are being able to convey information and making the recipient of the information able to understand the information conveyed by the speaker. Therefore, the existence of media can help teachers when explaining a material and students can understand the material to achieve the competencies. The existence of the media is essential for life, especially during the learning process, but the media is also essential to use in other ways. Therefore, a good media must have the following criteria: (1) The quality of the material content and objectives must be by the contents of KD and SK, (2) Quality in terms of ease of use and the quality of good media, (3) Quality in terms of an instructional system that prioritizes learning opportunities, helps to learn and can provide encouragement to students (Arsyad, 2011). It can be concluded that the media can support learning and overcome space limitations to clarify the content of the material presented so that the objectives to be achieved can be realized. The development of digital comic media is made concerning these principles.

Analyzing the needs was carried out in class IV with the homeroom teacher at SD Cluster VII, Buleleng District, distributing questionnaires and conducting short interviews. Needs analysis aims to find out what media is needed in the school/field. The questionnaire results are as follows: (1) $63.6 \%$ of teachers said that the scope of material in the available science textbooks was limited, (2) $54.5 \%$ of teachers stated that the media available in schools was limited. In addition, the development and use of media are applied to the teaching and learning process, the teacher only refers to the textbook in explaining the material, and the student's book is still shallow and uninteresting. Therefore, students' enthusiasm and interest in learning are reduced, so the teacher will have difficulty conveying the material in explaining the lesson. Which causes the material received to be not optimally understood by students. Related to this, media use during the learning process is still classified as less than optimal and rarely found. This is because the infrastructure and facilities are still inadequate, which causes students to experience boredom while studying and lack enthusiasm in participating in learning. Therefore, innovation is needed to overcome these problems. The innovation that can be done is by developing style topic material through the media.

After some of the above analysis has been done, it can proceed to the design stage. The design stage begins with determining the content of the topic or material based on the results of several analyzes carried out previously. The topic or material chosen in this media is style material. Then, draft a digital comic. The design consists of two parts: the design of the material's content and the design of the media form. At the design stage, the material's content is compiled by making a storyline from the comics and how much material is contained in the digital comic media to suit the primary goal of developing material through digital comic media. At the media design stage, making a media design is carried out using the Adobe Photoshop CC 2020 and Comic Life 3 applications, then making each character with the help of the Samsung App AR Zone application. The process of making comic designs is presented in Figure 1. 


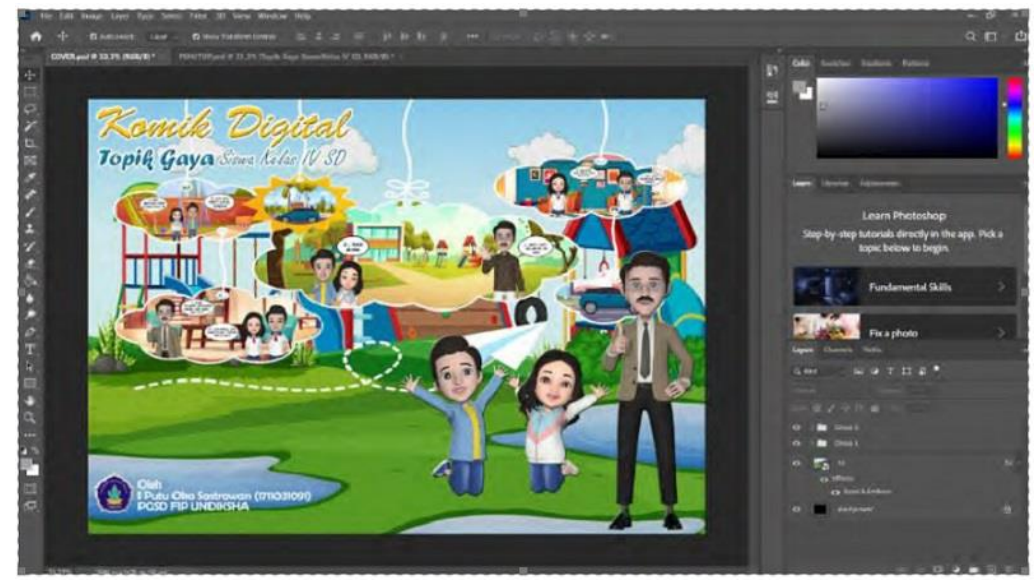

Figure 1. Comic Design

After the media and character designs have been created. The recording process uses the Samsung Voice Recorder application with the help of the AKG Microphone. The next stage is the editing stage of all materials that have been made from designs, characters, conversation content, voice recordings of each character, and music as accompaniment, into the form of animated videos using the Adobe Premiere Pro 2020 application with a ratio of 16: 9. The editing process is divided into several stages, namely: (1) making the cover/cover and opening prefix, (2) making content according to the storyline reference that has been made, (3) making the conclusion of the material, and (4) making the video cover. After the media design is completed, it continues to consult the design with the supervisor to get suggestions for improving the media design.

In the development stage, digital comic media are arranged according to the design and input from the supervisor. At the development stage, digital comic media were developed. The developed media consists of cover, opening prefix, content section, conclusion and closing section. The video's cover uses a background with attractive colour, containing characters and titles according to the chosen topic. The opening prefix section contains the title of the comic, the name of the creator, the target reader, the learning objectives and the introduction of the comic characters briefly. The video's back or end contains the editing application, the source of the material used, the author's biography, and an exciting closing slogan. The content section contains the style topics in the 7th-semester 2nd-grade 4th-grade elementary school theme. Each slide is arranged in an exciting and orderly manner that is adjusted to the storyline that has been made about the style topic material. While the last part, before closing the digital comic media, there is a conclusion from the style topic material, which contains a summary of the style topic material. The results of the comics that have been developed and have gone through several revisions can be seen in the following figure.

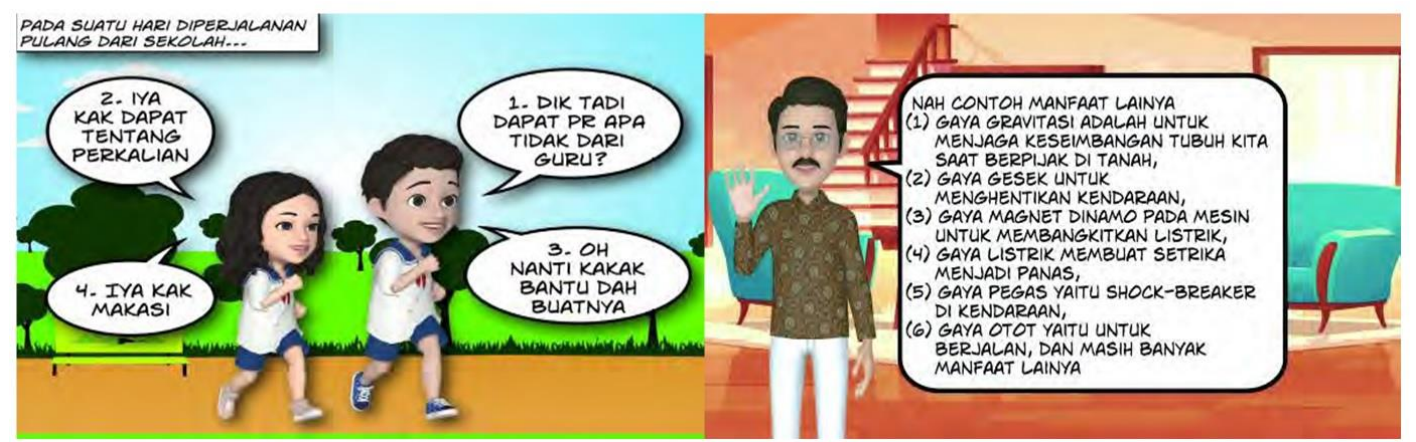

Figure 2. Digital Comic Results 
The data from the digital comic media test results were then analyzed to determine the validity of the digital comic media. In this analysis stage, the validity score of the digital comic media is then calculated, which is obtained from the instrument sheet for the assessment of experts and respondents. The data from the digital comic media that has been obtained is then converted into the respective guidelines. The results of the expert's assessment were converted into Aiken's validity index criteria to find out how the criteria for the validity of digital comic media were. Based on the results of data analysis, it is known that the validation scores of each digital comic media expert are: (1) 0.95 results from the assessment of material experts, (1) 0.95 results from media expert assessments. It is stated that the digital comic media on the topic of the style of the fourth-grade elementary school students as a whole from the results of the expert's assessment has been feasible or valid to be used in the learning process.

\section{Discussion}

First, the media has high content validity and high response. It is because the purpose of learning in digital comic media is by $\mathrm{KD}$. The material in comics is presented clearly and coherently and by the level of development of student characteristics. In addition, comics can explain material in comics which can encourage students' curiosity, and the validity of the content of digital comics media gets high validity criteria by material experts (Harmawati et al., 2020; Ntobuo et al., 2018). As well as the content and content of the material in the comics are displayed clearly, digital comic media can be accessed through various electronic media. The intonation of conversations between characters can be heard clearly, and the language in comics is easy to understand (Aggleton, 2019; Enteria \& Casumpang, 2019). In addition, the display of interesting digital comics makes students motivated in learning (Nugraheni, 2017; Reis et al., 2021). This is also in line with research suggesting that digital comic media with clear sound and attractive appearance can motivate students to learn it (Hidayah et al., 2018; Wahyudin et al., 2020). Digital comic media states that it is valid because of the aspects used in digital comic media that can support the learning process. This digital comic media has seven aspects: sound and text aspects, visual aspects, characterization aspects, overall appearance aspects, material aspects (content), linguistic aspects, and presentation aspects (Nugraheni, 2017).This shows that digital comic media can be used to support learning.

Second, digital comic media is by the characteristics of students at the concrete operational stage. Children still need an object or media intermediary, especially audio-visual media, to clarify the material so that it becomes concrete so that children do not think abstractly anymore (Bromberek-Dyzman et al., 2021; Liang et al., 2011). This is supported by previous research, which states that making media with audio-visual elements can convey a material that is easier to understand and clearer (Hilmi, 2017; Michelsanti et al., 2019). Therefore, the use of media, especially audio-visual media, is essential to make the learning process optimal for children's development (Pattemore \& Muñoz, 2020; Wang et al., 2020). With the use of media during the learning process, especially in this case, digital comic media can attract students' attention so that they are happy in learning and help concretize abstract material.

The results of his previous research also stated that the use of digital comic media increased motivation, cognitive learning outcomes, and affective learning outcomes (Sukmanasa et al., 2017). This digital comic media is different from the digital comic media that has been developed by previous research. The novelty of the media developed is making digital comic media packaged in the form of audio-visual videos containing unique characters, exciting backgrounds with full-colour, each voice. Each character delivers the material, accompaniment music to add to the atmosphere when listening to it and can be 
accessed anywhere through electronic media. The digital comic media created can be accessed on the Google Drive platform through electronic media devices. It is intended that teachers can use it in the learning process, and students can access digital comics directly through electronic media (Dwiasih \& Agung, 2021; Taufiq et al., 2020). It is done online or in a network so that the digital comic media created can be used to support material in the online learning process (Hobri et al., 2019; Yuniarti \& Radia, 2020).

Third, digital comics media have met the criteria for good media, namely as follows: (1) Digital comics in terms of the quality of the material content and objectives are by the contents of $\mathrm{KD}$ and SK. It is obtained from the analysis carried out on the applicable curriculum so that it is used as a reference in making media, (2) Digital comics in terms of convenience, the media is straightforward to use, and the quality of the media is good. It is obtained from the design and development stages of media that are well designed to be developed with good quality. So that it can help teachers in teaching, which can encourage students' interest in learning (Harmawati et al., 2020; Rahmata et al., 2020). This statement is supported by the results of previous research, which stated that the development of digital comic media that he had done received perfect media validation obtained from expert tests and field trials (Ntobuo et al., 2018).

It is shown that digital comics are feasible and can increase students' interest in reading and listening. Previous research has shown that using digital comics media can increase students' learning motivation, and some students like learning by using digital comics media (Enteria \& Casumpang, 2019; N. Hidayah \& Ulva, 2017). Research by other research results shows an increase in student learning outcomes with scores above the average (Nugraheni, 2017; Rohmanurmeta, F. M., \&Dewi, 2019). As well as other research shows that using comics media in the process can improve students' cognitive learning outcomes with the results of the validity of comics being in the excellent category (Ambaryani \& Airlanda, 2017). Therefore, digital comic media on the topic of style for fourth-grade elementary school students is an audio-visual media that can impact students. This influence leads to positive things, especially the cognitive development of children who will continue to develop. So by developing digital comic media, it is expected to add insight and knowledge of students and provide more understanding, primarily material about style. The use of digital comic media on the topic of style for fourth-grade elementary school students is suitable for use in science learning, especially style material. Electronic media and its assistance in delivering science material, especially style, make children happier in learning

\section{Conclusion}

By the results that have been described, this digital comic media has an influential role in improving learning for the better. So, the developed digital comics deserve to be used by getting a high category so that this digital comic media can be used as an alternative learning media.

\section{References}

Abdullah, R. 2017. (2017). Pembelajaran Dalam Perspektif Kreativitas Guru Dalam Pemanfaatan Media Pembelajaran. Lantanida Journal, 4(1), 37-49. https://doi.org/10.22373/lj.v4i1.1866

Aggleton, J. (2019). Defining digital comics: a British Library perspective. Journal of Graphic Novels and Comics, 10(4), 393-409. https://doi.org/10.1080/21504857.2018.1503189

Ambaryani, \& Airlanda, G. S. (2017). Pengembangan Media Komik Untuk Efektivitas Dan 
Meningkatkan Hasil Belajar Kognitif Materi Perubahan Lingkungan Fisik. Jurnal Pendidikan Surya Edukasi (JPSE), 3(1), 43-59. https://doi.org/10.37729/jpse.v3i1.3853 Andriani, N. (2019). Penerapan Media Komik Digital terhadap Pemahaman Pembelajaran Matematis Siswa SMP. Diskusi Panel Nasional Pendidikan Matematika, 5(1), 31-38.

Arista, F. S., \& Kuswanto, H. (2018). Virtual physics laboratory application based on the android smartphone to improve learning independence and conceptual understanding. International Journal of Instruction, 11(1), 1-16. https://doi.org/10.12973/iji.2018.1111a

Arsyad, A. (2011). Media Pembelajaran. PT Raja Grafindo Persada.

Astuti, M., Arifin, Z., Mutohhari, F., \& Nurtanto, M. (2021). Competency of Digital Technology: The Maturity Levels of Teachers and Students in Vocational Education in Indonesia. Journal of Education Technology, 5(2), 254-262. https://doi.org/10.23887/jet.v5i3.35108

Bromberek-Dyzman, K., Jankowiak, K., \& Chełminiak, P. (2021). Modality matters: Testing bilingual irony comprehension in the textual, auditory, and audio-visual modality. Journal of Pragmatics, 180. https://doi.org/10.1016/j.pragma.2021.05.007

Candra Lestari, N. P. (2018). Penerapan Model Pembelajaran Kooperatif Tipe Nht Berbantuan Media Audio Visual Untuk Meningkatkan Hasil Belajar IPA. Journal of Education Action Research, 2(4), 355. https://doi.org/10.23887/jear.v2i4.16331

Chauhan, S. (2017). A meta-analysis of the impact of technology on learning effectiveness of elementary students. Computers \& Education, 105, 14-30. https://doi.org/10.1016/j.compedu.2016.11.005

Dwiasih, A. A. I., \& Agung, A. A. G. (2021). The Development of Fabel E-Comic in Bahasa Indonesia Lesson for Grade II of Elementary School. Advances in Social Science, Education and Humanities Research. https://doi.org/10.2991/assehr.k.210407.284

Enteria, O., \& Casumpang, P. F. H. (2019). Effectiveness of Developed Comic Strips as Intructional Materials in Teaching Specific Science Concepts. International Journal for Innovation Education and Research, 7(10), 876-882. https://doi.org/10.31686/ijier.vol7.iss10.1835

Fauzan, M., Gani, A., \& Syukri, M. (2017). Penerapan Model Problem Based Learning Pada Pembelajaran Materi Sistem Tata Surya Untuk Meningkatkan Hasil Belajar Siswa. $\begin{array}{llll}\text { Jurnal Pendidikan Sains } & \text { Indonesia, }\end{array}$ http://jurnal.unsyiah.ac.id/JPSI/article/view/8404

Gading, I. K., \& Kharisma, K. D. (2017). Pengaruh Model Pembelajaran Kooperatif Tipe Make A Match Berbantuan Media Audio Visual Terhadap Hasil Belajar IPS Sekolah Dasar. International Journal of Elementary Education, 1(2), 153-160. http://dx.doi.org/10.23887/ijee.v1i2.11608

Genc, M., Genc, T., \& Rasgele, P. G. (2018). Effects of nature-based environmental education on the attitudes of 7 th grade students towards the environment and living organisms and affective tendency. International Research in Geographical and Environmental Education, 27(4), 326-340. https://doi.org/10.1080/10382046.2017.1382211

Harmawati, D., Hasanah, N., Belwawin, S. M., \& Hidayat, S. H. (2020). Developing of an educative comic on the theme of clean and healthy life for grade 2 students of the elementary schools of YPPK Biankuk Merauke. Enfermería Clínica, 30(2). https://doi.org/10.1016/j.enfcli.2019.07.120

Herreras, E. B. (2017). Risk low math performance PISA 2012: Impact of assistance to Early Childhood Education and other possible cognitive variables. Acta de Investigación Psicológica, 7(1). https://doi.org/10.1016/j.aipprr.2017.02.001

Hidayah, N., \& Ulva, R. K. (2017). Pengembangan Media Pembelajaran Berbasis Komik 
Pada Mata Pelajaran Ilmu Pengetahuan Sosial Kelas IV MI Nurul Hidayah Roworejo Negerikaton Pesawaran. Jurnal Pendidikan Dan Pembelajaran Dasar, 4(1), 34-46. https://doi.org/10.24042/terampil.v4i1.1804

Hidayah, P., Untari, M. F. A., \& Wardana, M. Y. S. (2018). Pengembangan Media Sepeda (Sistem Peredaran Darah) dalam Pembelajaran IPA di Sekolah Dasar. International Journal of Elementary Education, 2(4), 306-310. https://doi.org/10.23887/ijee.v2i4.16109

Hidayah, Y. F., Siswandari, S., \& Sudiyanto, S. (2017). Pengembangan Media Komik Digital Akuntansi Pada Materi Menyusun Laporan Rekonsiliasi Bank Untuk Siswa SMK. Jurnal Pendidikan Dan Kebudayaan, 2(1), 135-146. https://doi.org/10.24832/jpnk.v2i2.588

Hilmi, H. (2017). Efektivitas Penggunaan Media Gambar Dalam Pembelajaran Bahasa Arab. Lantanida Journal, 4(2), 128-135. https://doi.org/10.22373/lj.v4i2.1885

Hobri, Murtikusuma, R. P., \& Hermawan, L. I. (2019). Development of e-comic using pixton and kelase web on linear program of two variables assisted by geogebra. Journal of Physics: Conference Series, 1265, 012010. https://doi.org/10.1088/17426596/1265/1/012010

Huang, S.-Y., Kuo, Y.-H., \& Chen, H.-C. (2020). Applying Digital Escape Rooms Infused with Science Teaching in Elementary School: Learning Performance, Learning Motivation, and Problem-Solving Ability. Journal Pre-Proof, 1-46. https://doi.org/10.1016/j.tsc.2020.100681

Ilhami, R. S., \& Rimantho, D. (2017). Penilaian Kinerja Karyawan dengan Metode AHP dan Rating Scale. Jurnal Optimasi Sistem Industri, 16(2). https://doi.org/10.25077/josi.v16.n2.p150-157.2017

Indriani. (2019). Hasil Pisa Tunjukkan Perspektif Pendidikan Indonesia. Antarnews.

Jampel, I. N., \& Puspita, K. R. (2017). Peningkatan Hasil Belajar Siswa Sekolah Dasar Melalui Aktivitas Pembelajaran Mengamati Berbantuan Audiovisual. International Journal of Elementary Education, 1(3), 197-102. https://doi.org/10.23887/ijee.v1i3.10156

Jundu, R., Tuwa, P. H., \& Seliman, R. (2020). Hasil Belajar IPA Siswa SD di Daerah Tertinggal dengan Penerapan Model Pembelajaran Inkuiri Terbimbing. Scholaria: Jurnal Pendidikan Dan Kebudayaan, 10(2), 103-111. https://doi.org/10.24246/j.js.2020.v10.i2.p103-111

Koesoemadinata, M. I. P. (2018). Visual Adaptation Of Wayang Characters In Teguh Santosa's Comic Art. MUDRA: Jurnal Seni Budaya, 33(3). https://doi.org/10.31091/mudra.v33i3.544

Lastefo, A. R. (2018). Meningkatkan Hasil Belajar IPA Melalui Model Group Investigation Berbantuan Video pada Siswa Kelas V. International Journal of Elementary Education, 2(1), 1-7. http://dx.doi.org/10.23887/jppp.v1i3.12631

Liang, Y., Zheng, T., \& Wang, M. (2011). English audio-visual teaching mode and its teaching environment construction - Henan Institute of Science and Technology as the example. 2011 International Conference on Multimedia Technology, 3050-3053. https://doi.org/10.1109/ICMT.2011.6001924

Lo, J.-H., Lai, Y.-F., \& Hsu, T.-L. (2021). The Study of AR-Based Learning for Natural Science Inquiry Activities in Taiwan's Elementary School from the Perspective of Sustainable Development. Sustainability, 13(3). https://doi.org/10.3390/su13116283

Maison, M., Haryanto, H., Ernawati, M. D. W., Ningsih, Y., Jannah, N., Puspitasari, T. O., \& Putra, D. S. (2020). Comparison of student attitudes towards natural sciences. International Journal of Evaluation and Research in Education, 9(1), 54-61. https://doi.org/10.11591/ijere.v9i1.20394 
Michelsanti, D., Tan, Z.-H., Sigurdsson, S., \& Jensen, J. (2019). Deep-learning-based audiovisual speech enhancement in presence of Lombard effect. Speech Communication, 115. https://doi.org/10.1016/j.specom.2019.10.006

Muhtadi, D., Wahyudin, Kartasasmita, B. G., \& Prahmana, R. C. I. (2018). The Integration of technology in teaching mathematics. Journal of Physics: Conference Series, 943(1), 19. https://doi.org/10.1088/1742-6596/943/1/012020

Nafis, Z. F. N. (2016). Pengembangan Media Pembelajaran Komik Audio Visual Bagi Pembelajaran Ekonomi Materi Kurs Valuta Asing Di Sma Negeri 8 Malang. Jurnal $J P E, 9(2)$. http://journal.um.ac.id/index.php/jpe/article/view/7162

Ntobuo, N. E., Arbie, A., \& Amali, L. N. (2018). The Development of Gravity Comic Learning Media Based on Gorontalo Culture. Jurnal Pendidikan IPA Indonesia, 7(2), 246-251. https://doi.org/10.15294/jpii.v7i2.14344

Nugrahanto, S., \& Zuchdi, D. (2019). Indonesia PISA Result and Impact on the Reading Learning Program in Indonesia. International Conference on Interdisciplinary Language, Literature and Education, 373-377. https://doi.org/10.2991/icille-18.2019.77

Nugraheni, N. (2017). Penerapan Media Komik Pada Pembelajaran Matematika Di Sekolah Dasar. Refleksi Edukatika: Jurnal Ilmiah Kependidikan, 7(2), 111-117. https://doi.org/10.24176/re.v7i2.1587

Pattemore, A., \& Muñoz, C. (2020). Learning L2 constructions from captioned audio-visual exposure: The effect of learner-related factors. System, 93. https://doi.org/10.1016/j.system.2020.102303

Perignat, E., \& Katz-Buonincontro, J. (2019). STEAM in practice and research: An integrative literature review. Thinking Skills and Creativity, 31, 31-43. https://doi.org/10.1016/j.tsc.2018.10.002

Permana, E. P., \& Nourmavita, D. (2017). Pengembangan Multimedia Interaktif Pada Mata Pelajaran Ipa Materi Mendeskripsikan Daur Hidup Hewan Di Lingkungan Sekitar Siswa Kelas Iv Sekolah Dasar. Jurnal PGSD, 10(2), 79-85. https://doi.org/10.33369/pgsd.10.2.79-85

Puspitarini, Y. D., \& Hanif, M. (2019). Using Learning Media to Increase Learning Motivation in Elementary School. Anatolian Journal of Education, 4(2), 53-60. https://doi.org/10.29333/aje.2019.426a

Rahmata, A., Tuljannah, LaiRahmata, A., Tuljannah, L., Chotimah, S. C., \& Fiangga, S. (2020). Validitas E-Comic Matematika Berbasis Pemecahan Masalah pada Materi Kesebangunan. Jurnal Review Pembelajaran Matematika, 5(1), 53-65. https://doi.org/10.15642/jrpm.2020.5.1.53-65

Reis, F., Palermo, T. M., Acalantis, L., Nogueira, L. C., \& Meziat-Filho, N. (2021). "A journey to learn about pain": the development and validation of a comic book about pain neuroscience education for children. Brazilian Journal of Physical Therapy, 2. https://doi.org/10.1016/j.bjpt.2021.04.009

Riwanto, M. A., \& Wulandari, M. P. (2018). Efektivitas Penggunaan Media Komik Digital (Cartoon Story Maker) Dalam Pembelajaran Tema Selalu Berhemat Energi. Jurnal Pancar, 2(1), 14-18. https://ejournal.unugha.ac.id/index.php/pancar/article/view/195

Rohmanurmeta, F. M., \&Dewi, C. (2019). Pengembangan Komik Digital Pelestarian Lingkungan Berbasis Nilai Karakter Religi Untuk Pembelajaran Tematik Pada Siswa Sekolah Dasar. MUADDIB: Studi Kependidikan Dan Keislaman, 9(2), 100-109. https://doi.org/10.24269/muaddib.v1i2.1213

Rovers, S. F. E., Clarebout, G.Rovers, S. F. E., Clarebout, G., Savelberg, H. H. C. M., \& Merriënboer, V. (2018). Improving student expectations of learning in a problem-based environment. Computers in Human Behavior, 87, 416-423. https://doi.org/10.1016/j.chb.2018.02.016 
Saripudin, E., Sari, I. J., \& Mukhtar, M. (2018). Using Macro Flash Animation Media on Motion Material to Improve Learning Achievement for Learning Science in Junior High School. Jurnal Penelitian Dan Pembelajaran IPA, 4(1), 68-75. https://doi.org/10.30870/jppi.v4i1.3316

Shaik Alavudeen, S., Easwaran, V., Iqbal Mir, J., Shahrani, S. M., Ali Aseeri, A., Abdullah Khan, N., Mohammed Almodeer, A., \& Abdullah Asiri, A. (2021). The influence of COVID-19 related psychological and demographic variables on the effectiveness of elearning among health care students in the southern region of Saudi Arabia. Saudi Pharmaceutical Journal. https://doi.org/10.1016/j.jsps.2021.05.009

Sukmanasa, E., Windiyani, T., \& Novita, L. (2017). Pengembangan Media Pembelajaran Komik Digital Pada Mata Pelajaran Ilmu Pengetahuan Sosial Bagi Siswa Kelas V Sekolah Dasar Di Kota Bogor. JPsd (Jurnal Pendidikan Sekolah Dasar), 3(2), 171-185. http://dx.doi.org/10.30870/jpsd.v3i2.2138

Sukmanasa, Elly, Windiyani, T., \& Novita, L. (2017). Pengembangan Media Pembelajaran Komik Digital Pada Mata Pelajaran Ilmu Pengetahuan Sosial Bagi Siswa Kelas V Sekolah Dasar Di Kota Bogor. Jurnal Pendidikan Sekolah Dasar, 3(2), 171. https://doi.org/10.30870/jpsd.v3i2.2138

Sung, E. (2017). The influence of visualization tendency on problem-solving ability and learning achievement of primary school students in South Korea. Thinking Skills and Creativity, 26, 168-175. https://doi.org/10.1016/j.tsc.2017.10

Suryantari, N. M. A., Pudjawan, K., \& Wibawa, I. M. C. (2019). Pengaruh Model Pembelajaran Inkuiri Terbimbing Berbantuan Media Benda Konkret Terhadap Sikap Ilmiah dan Hasil Belajar IPA. International Journal of Elementary Education, 3(3), 316-326. https://doi.org/10.23887/ijee.v3i3.19445

Taufiq, M., Wijayanti, A., \& Fajriah, E. (2020). The implementation of e-comic earth layer to enhance students' self-directed learning. Journal of Physics: Conference Series, 1567, 022070. https://doi.org/10.1088/1742-6596/1567/2/022070

Tuma, F. (2021). The use of educational technology for interactive teaching in lectures. Annals of Medicine and Surgery 62, 231-235. https://doi.org/10.1016/j.amsu.2021.01.051

Wahyudin, A. Y., Jepri, D., Simamora, M. W., Pratiwi, I. W., \& Rina, A. (2020). Penggunaan komik digital toondoo dalam pembelajaran Bahasa inggris tingkat Sekolah menengah. Jurnal of Social and Tevhnologi for Community Service, 1(1), 1-6. https://doi.org/10.33365/jta.v1i1.673

Wang, Z., Wang, L., \& Huang, H. (2020). Joint low rank embedded multiple features learning for audio-visual emotion recognition. Neurocomputing, 338. https://doi.org/10.1016/j.neucom.2020.01.017

Wulandari, I. G. A. A. M., Sudatha, I. G. W., \& Simamora, A. H. (2020). Pengembangan Pembelajaran Blended Pada Mata Kuliah Ahara Yoga Semester II di IHDN Denpasar. Jurnal Edutech Undiksha, 8(1), 1. https://doi.org/10.23887/jeu.v8i1.26459

Yulianti, D., Khanafiyah, S., \& Sulistyorini, S. (2016). Inquiry-based science comic physics series integrated with character education. Jurnal Pendidikan IPA Indonesia, 5(1), 3844. https://doi.org/10.15294/jpii.v5i1.5787

Yuniarti, A., \& Radia, E. H. (2020). Development of Comic Mathematics Teaching Materials on Flat- Building Material to Increase Reading Interest in Class IV Elementary School Students. Journal of Education Technology, 4, 415-423. https://doi.org/10.23887/jet.v4i4.30034 